\title{
The Impact of Digital Media Advertising on Consumer Behavior Intention: The Moderating Role of Brand Trust
}

\author{
Assia Enehasse \\ Master Student, Istanbul Commerce University, Social Science Institute \\ Mehmet Sağlam \\ Asst. Prof. \\ Istanbul Commerce University, Faculty of Business
}

\begin{abstract}
The present investigation was done to distinguish the impact of the digital media marketing, brand trust on consumer behavior. Additionally, the moderating impact of the brand trust on the connection between the digital media advertising and the consumer behavior was examined. The consumers of brand client in turkey were the members of this examination. The information were gathered utilizing the convenience sampling and through the survey procedure. 150 questionnaires were appropriated among the consumers. The confirmatory factor analysis and the structural equation model technique was used to examine the information. The outcomes demonstrated that the digital media advertising had a noteworthy and beneficial outcome on the consumer behavior. Also, brand trust moderated the connection between the digital media marketing and the consumer behavior. In the greater part of the examination considers, the moderating impact of brand trust has been overlooked in the earlier investigations, and the present investigation has filled this gap. The current investigation had a few confinements, and toward the finish of proposition further proposals have likewise been given.
\end{abstract}

Keywords: Brand trust, digital media advertising, consumer behavior intention

DOI: $10.7176 / \mathrm{JMCR} / 68-04$

Publication date:May $31^{\text {st }} 2020$

\section{Introduction}

With the passage of time, digital technology is adopting new methods for doing business. If businesses and companies related to conventional concede the existence and digital technology's effect on business, such companies will not exist. For Example, in 1990, Nokia is a popular and trusted company of mobile phones. Because of averseness to regulate with advance technology, Nokia is nowhere as a competitor in mobile industry. Similarly, today, a major challenge is faced by traditional retailers, as new generation shoppers seek out shopping through online (Krbová \& Pavelek, 2015). With the changing lifestyle, we have to focus on new adjustment of technology and accommodate new changes in traditional businesses that have changed the way we live today. Today, the modern world is especially fenced with technology, therefore, it is pertinent for understanding how digital media marketing affects consumer behavior.

Social media is a huge key aspect of digital marketing, which is something the company needs to consider to market nowadays. Social media is a term which is use to describe the media type that is based on the transformation and interaction between online people. Nowadays people spend their waking hours on multiple tasks and multiple media platforms simultaneously, someone can browse the Internet, text their friends and talk on the phone while drinking a cup of local coffee. Shop, these people were recently called - Digital Native. Today, marketers are using new tools to reach out the natives of digital media. In fact, the question for most organizations, now, is not to use social media as part of the communication mix, but how much to use (Dutton, Coady, Pisoni, \& Woody, 2010). Social media marketing is becoming the most important thing to analyze.

Different statistics are developed by DEI Worldwide (2008): almost 70\% users of internet visited the different sites of social media for information, $49 \%$ people decide to purchase a product from these sites on the base of available information, $60 \%$ claimed that they used social media for sending info about a product to others through online and $45 \%$ people seeking information on the verbal part. The report concluded that companies that do not implement social media in their online marketing strategy do not lose the opportunity to reach consumers. Technologies of new era are associated with social media that help people to buy or sell and interact them with different people through different sites on Internet (Al-Dhuhli \& Ismael, 2013). The way of an individual's purchase has changed and improved significantly over the decades. Some consumers are still prefer physical store like big mall but most of them prefer online shopping (Lu \& Hsiao, 2009). Almost all companies use social media extensively for advertising and promoting themselves. Many Big brands also use social media to showcase their strong animations and friendly customer relationships (Kumar \& Rajaram, n.d.).

According to Wang \& Kim, (2017) digital media marketing is actively growing and is being addressed by educators and practitioners around the world. Today, everybody is using smartphones, tabs and laptops for their access on social media. Currently, consumers use many platforms of social media such as Facebook, Twitter, 
YouTube, WhatsApp and LinkedIn for interaction toward friends and family. As social media marketing has become a largest and latest practices for engaging the customers to sell goods and services (Dahnil, Marzuki, Langgat, \& Fabeil, 2014). Social media marketing enables organizations to build and maintain stakeholder relationships by creating online marketing offerings and delivering on social media platforms (Yadav \& Rahman, 2017).

For achieving brand loyalty, digital media marketing need special attention and strategic planning. It a platform of marketing, where companies require to move from "trying to sell" to "making contact" with customers. Usually, brands keep a distance from large campaigns and restrict yourself with small actions because these actions easily achieve their goal in short period (Coon, 2010). The reviews of consumers about product on social media can create an image and it will be positive or negative that affect the decision of consumer buying (Vij \& Sharma, 2013). However, in addition to use social media options for marketing, less understanding of the impact that social media marketing can have on different products and services should be discussed (Ahmed \& Zahid, 2014). Therefore, there is a need for more extensive research on various social networking sites (De Vries, Gensler, \& Leeflang, 2012). Therefore, this study is a response to a previous study. So, this study conducted to see the impact that digital media marketing can have on consumer behavior with a moderating effect of brand trust.

\subsection{Research Objectives}

The objectives of this study are:

1. To determine the impact of Digital media marketing on consumer behavior.

2. To determine the impact of Digital media marketing on brand trust

3. To determine the moderate effect of brand trust on the relationship of Digital media marketing with consumer behavior.

\section{Literature Reviews}

\subsection{Digital Media Marketing}

Digital media marketing is a term used to depict the incorporated promoting administrations used to pull in, connect with and convert clients on online. Digital media marketing uses different channels, for example, c content marketing, influencer marketing, SEO, social media and online advertising to assist brands with associating with clients and reveal execution of advertising programs progressively. (Lee Oden, 2014).

Digital media marketing, as indicated by McClure (2009), is something beyond a popular expression. Today it is a lifestyle and an enormous part of individuals' ways of life, because of the ascent in online networks where individuals share basic interests and stories with one another. Businesses see the power level that social media has over consumers; digital media marketing has made new difficulties for promoters, organizations and strategists. Current advertisers are seeing how these online instruments can spread their planned message through online discussions, which has reinforced the intensity of consumer-to-consumer discussions in the commercial center (McClure 2009). This enhancement can be best observed where conventional Media (e.g., papers, TV) are enhanced by social media (e.g., websites, YouTube, conversation discussions and long range informal communication locales, Facebook, Twitter, My-Space and LinkedIn). According to McClure (2009), digital media marketing is more than just a buzzword. Due to the rise of online communities that share common lifestyles and stories with each other, this is a lifestyle and a huge part of people's lifestyles.

While considering social media as a promoting device be that as it may, it is imperative to look at how innovation has made new opportunities just as introduced new difficulties. As far as new chances, Ahlberg (2010) suggests that social media has encouraged new ways for ventures to reinforce and extend associations with clients and make brands by using web recordings, Facebook, websites and microsites. In spite of these new chances, numerous new difficulties exist for overseeing client relations. For instance, if negative social media comments are made about a product, services or an organization, new or returning clients might be affected contrarily and choose to locate an elective supplier or merchant. Right now, social media marketers are obliged to convey for example talk and listen in to their customers inside online networks about related items and services they bring to the table (Weber 2009). Through this single demonstration, the whole standards of marketing turn the consumer from unilateral communications of products and services to consumers.

\subsection{Consumer behavior}

In considering the field of promoting, publicizing and selling, it can't be questioned that a buy intention will in general happen at decision making phase where the consumer has built up a clear status to continue towards an item or brand (Dodds, Monroe, and Grewal, 1991; Wells, Valacich, and Hess, 2011). This purchase intention is a basic pointer for assessing the behavior of consumer since it can measure the probability of a shopper to buy an item. The higher the purchase intention, the higher a purchaser's availability to buy an item.

In an ongoing report directed by Mirabi, Akbariyeh, and Tahmasebifard (2015), it is discovered that components, for example, item quality, brand and notice can be the most significant elements that have 
contribution in purchase intention of customers. These variables go about as the very purpose behind organizations to contribute more on the advertising endeavors accomplished through novel methods other than conventional methodologies as the two methodologies can assist with boosting their pieces of the overall industry. Consumer behavior had utilized as a key develop in marketing studies in an assortment of settings yet they incorporate changing factors, for example, attitude of consumers (Hidayat and Diwasasri, 2013), perceived value (Shaharudin, Pani, Mansor, and Elias, 2010), risk, convenience and the usability (Faqih, 2013). In an online domain alone, numerous examinations (e.g., Thamizhvanan and Xavier, 2013; Weisberg, Te'eni, and Arman, 2011; Rose, Clark, Samouel, and Hair; 2012) have investigated the variables that could influence the purchase intention of consumers. In their investigation, Chang, Cheung, and Lai (2005) recognize in excess of 80 factors as forerunners of consumer behavior. These were classified as the apparent qualities of the sites, item attributes and purchaser attributes. Realizing that it is beyond the realm of imagination to expect to investigate all the factors that could influence consumer behavior, this examination is along these lines confined to research the impact of social network marketing and consumer engagement on purchase intention.

The development of social media websites, for example, Facebook, Twitter and Youtube has given consumers noteworthy chances for sharing and dispersing data and substance about a related item or brand utilized. Accordingly, buyers have gotten increasingly enlightening and worried about getting data on item includes before making any buy (Ahmed and Zahid, 2014). This marvel demonstrates the appropriate job of social media marketing and buyer commitment in giving data to different clients along these lines, assembling their inclinations and decisions of procurement.

\subsection{Brand Trust}

Trust can be characterized as the degree to which a buyer accepts that a specific brand fulfills their longing (Chinomona, 2016). Brand trust is a significant factor on the client practices when the acquisition of the item; and it causes long haul steadfastness just as reinforces the relations between two parties (Liu, Li, Mizerski, \&Soh, 2012). Jin, Line and Merkebu (2015) and Geçti and Zengin (2013) are of the view that brand trust is the client's readiness to depend on the capacity of a brand to play out its capacity true to form. Moreover, brand trust is characterized by Chinomona, Mahlangu and Pooe (2013) as a consumers certain convictions that the person can depend on the brand to convey guaranteed services or items. It tends to be deciphered that brand trust is made and created by direct encounters of customers by means of brands (Kabadayi and Alan, 2012). As per Cakmak (2016) brand trust is depicted as a protected inclination which consumer feels that brand being referred to will live up to their own desires. In addition, trust can decrease the consumer's vulnerability, on the grounds that the purchaser not just realizes that brand can merit trusting, yet in addition imagines that reliable, sheltered and legit utilization situation is the significant connection of the brand trust (Soong, Kao and Juang, 2011). Drawing induction from the above portrayals of brand trust, it is doubtful to clarify that when clients have a trust to the brand, rehash buy conduct will be made, which prompts pledge to the brand, and the connection between brands and clients can be developed.

As indicated by Rousseau, Sitkin, Burt, and Camerer (1998) trust is a mental state wherein people are happy to acknowledge helplessness because of their uplifting desires for the intention and behavior of another. A trust infringement happens when somebody exhibits an absence of aptitudes required for a job, or neglects to maintain significant moral standards (Mayer, Davis, and Schoorman, 1995). These are pointers that advancement and maintainability of trust in hierarchical setting is based upon the satisfaction of guarantees made to clients. Morgan and Hunt (1994) characterize trust as a condition that exists when someone has the certainty to take part involved with another dependable and legit party. Drawing surmising from this definition, it is doubtful to agree that such components as certainty and unwavering quality are critical in building trust. Mayer, Davis and Schoorman (1995) in their own view gave one general meaning of this build by saying that it is the eagerness of a gathering to be helpless against the activities of another gathering dependent on the desire that the other will play out a specific activity critical to the trustor, regardless of the capacity to screen or control the other party. As per Dithan (2011) speculations of social psychology assert state that trust comprises of two basic components: trust in the accomplice's trustworthiness and trust in the accomplice's kindness. He kept up that trustworthiness is the conviction that one's accomplice remains by its promise, while kindheartedness, as he would see it is the conviction that one's accomplice is keen on the organization's government assistance and won't take sudden activities which will contrarily affect the organization.

\subsection{Relationship between Digital Media Marketing and Consumer behavior}

Different examinations had led on the social media marketing and its impact on consumer behavior specially the purchase intention. The examination by Vafaei \& Fekete-Farkas, (2017) inspected the effect of online social network on customers purchasing decision procedure in nourishment retailer shops in Sweden. The specialists found that online social network effect the decision process of consumers to various degree with respect to nourishment retailer shops. Likewise, they found that accommodation was the principle purpose behind this 
behavior. Due to these comfort buyers invest more energy in it. Be that as it may, these highlights permit clients to collaborate with markets and different clients and reach to remarks on grocery stores Facebook's page. The investigation by Groß, (2015) intended to clarify the impact of social media on purchasing decision process of consumers and if the impact has various levels at the different phases of this procedure. The examination reasoned that the impact of social media has various levels as per the stages the buyers experience during the process of purchasing decision making. Contingent upon the phases of the procedure of decision making, the purchasers demonstrated to be pretty much affected by online networking.

Ahmed \& Zahid, (2014); Ziyadin, Doszhan, Borodin, Omarova, \& Ilyas, (2019) intended to look at the effect of social media marketing on brand value and client relationship management regarding buy expectation. The results of this examination showed that most critical factor which affected the purchase intention is customer relationship management. It additionally inferred that social media marketing decidedly affected client connections and brand value. Results additionally demonstrated that social media marketing doesn't legitimately influence the purchase intention of consumers, consumer behavior expanded when garments brands care about them, at that point clients connect genuinely with the brand as well as client's mindfulness about the brand, fulfillment and verbal increase the purchase intention of consumers. Digital media marketing encourages speedy and viral conveyance offers and it catches the eye of customers decently fast and this can produce an expanded buy goal (Baird \& Parasnis, 2011). Dehghani \& Tumer, (2015) find that Facebook publicizing can fundamentally influence the brand picture and brand value by offering more noteworthy intuitiveness, personalization and criticism. This procedure can thusly, influence consumer behaviors. Pjero \& Kërcini, (2015); Sawaftah, Calıcıoglu, \& Awadallah, (2020) in their investigation concentrating on digital media and its effect on behavior of consumer see that data about items and administrations offered in the virtual world can decidedly affect the consumer buying intention. A customer might be affected by eWOM by different clients. Most developing countries like Turkey, a comparative pattern including the virtual world is additionally surfacing quickly (Kim, Sung, \& Kang, 2014). An examination led by Hwang \& Zhang, (2018) uncovers that Turkish utilizing online social medium have had their buying decision appropriately impacted by digital media utilization. They utilize these online social mediums to assemble data about various 'organizations, brands, items and services' and the vast majority of them decided to utilize Facebook. This wonder is because of the promoting done through digital media. Based on these findings, the hypothesis is formulated as follows:

H1: Digital media marketing has a positive impact on consumer behavior

\subsection{Relationship between Digital Media Marketing and Brand Trust}

As indicated by Pintado, Sanchez, Carcelén, \& Alameda, (2017), one of the significant prerequisites of being strong brand in online condition and social media is 'trust'. Trust towards a brand is a desire for the vows to be kept by the brand. In advertising, trust is generally viewed as the ability of a client to visit a brand over again (Mckinney \& Benson, 2013). As indicated by Tatar \& Eren-Erdoğmuş, (2016), trust is bidirectional; one heading is conviction and the other is goal. Conviction for the client is a desire for the brand staying faithful to its commitments and goal for the brand is deciding the need as client desires. As per (Atulkar, 2020), trust is the inspirational desires for the client towards the brand mentally and feeling free. Social networking is seen by purchasers as progressively dependable contrasted with customary components of the promotional mix (Habibi, Laroche, \& Richard, 2014). This may be credited to the way that online life gives intuitive correspondence, moment criticism, and progressively target buyer created content.

As per Schivinski \& Dabrowski, (2016) brand trust are impacted emphatically by computerized media communication. The outcomes indicated that brand trust impact on purchase intention. Another nearby investigation of SAN, (2016) endeavored to clarify how the impact of social media is pondered the process of decision making of consumers. The examination found that the impact of social media has various levels when client experiencing different phases of the customers' buying decision procedure. The consequences of the exploration affirmed that consumers in Saudi Arabia are effectively utilizing social media platforms as an instrument when they engage in decision of buying a product. Nonetheless, buyers are viewed as reluctant to imparting their opinions and word-of-mouth to different clients through social media platforms. It further endorsed that Saudi consumers were influenced by online networking in their buy choice. The exploration by Akhtar, Ahmed, Jafar, Rizwan, \& Nawaz, (2016) indicated that there is a positive connection between internet based life advertising and buyer buy aim. It affirmed that as the organizations increment their spending on showcasing via web-based networking media, the gainfulness of the organizations likewise improved. Internet based life promoting helps the organizations to increase serious edge and upgrade the productivity of organizations. In this way; we hypothesized that:

H2: Digital media marketing has a positive impact on Brand Trust

\subsection{Moderating role of Brand Trust}

The present study argues that brand trust moderated the relationship between social media marketing and 
behavioral intentions, in particular, purchase intention and word of mouth. Evaluators specify under what conditions a particular outcome effect variables and in this study, purchase intentions and WOM (Chang \& Wu, 2014; Kim et al., 2014). Brand trust Dastan \& Geçti, (2014) is explained by the consumer's willingness to depend on other people in which they have a degree of trust. The Foundation has a strong connection with each other and with personal behaviors, which is important in the development of attitudes and behaviors towards brands. Tedeschi, Galli, \& Martini, (2017) define brand trust as "the desire of the average consumer to believe in its ability to perform its particular function" (p. 82). It suggests the importance of trust in any relationship and its role as a key mediator of relational exchange. Other scholars such as (Bhandari \& Rodgers, 2018) have made enormous contributions to the role of trust in building relationships, and they believe to play a positive mediating role between online customer relationships and behavior. Objectives in the online environment. But Tedeschi et al., (2017) emphasize that the nature of online platforms, if not reorganized, can lead to a lack of trust among consumers in the future and, therefore, to create trustworthy systems.

In addition Yang \& Chiang, (2017) found that lack of trust in online platforms can lead to a client's reluctance to participate in online marketing, so it is always necessary to establish trust. Trust is chosen as a moderating variable between digital media marketing and purchase intention. This is influenced by the intellectual work of (Sung \& Kim, 2010), that belief significantly mediates the relationship between brand-related participation and customer intent, which is referred to as behavioral intention. The concept of trust in the evaluation of social networks has received particular attention in the literature on relationship marketing (Mckinney \& Benson, 2013) and in some recent trust literature. Most studies have described trust as an antecedent variable and sometimes as a consequence (Chinomona, 2016), and some studies suggest that trust plays a significant role in enhancing information exchange and knowledge integration (Swift \& Hwang, 2013). Trust has been disclosed to be, the eagerness of a client to depend/depend on the association's declaration towards them accepting that the firm would be straightforward towards them (Ngo, Liu, Moritaka, \& Fukuda, 2020). Most investigations have recognized trust as an intervening variable in social trades (Boateng \& Narteh, 2016). Again Arnott, Wilson, Mukherjee, \& Nath, (2007) discovered that trust plays a key noteworthy interceding constructs and behavioral intentions on online platforms. Phua, Jin, \& Kim, (2017) discovered that trust altogether directed the connection between brands related interest in Social Network Sites (SNS), brand network distinguishing proof and enrollment expectation. The investigation found that there is a positive moderating impact of trust between consumer who involve in decision brand-related conversations via social media marketing and correspondence, distinguishing proof and participation expectation with different buyers.

H3: Brand trust moderate the relationship of digital media advertising and consumer behavior intention

\subsection{Conceptual Model}

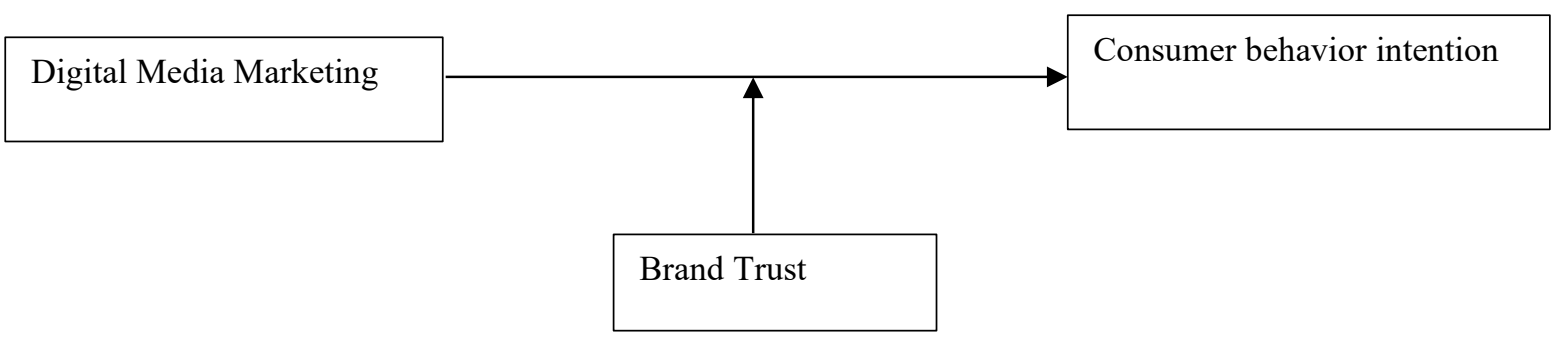

\section{Methodology}

\subsection{Purpose of the Study}

The purpose of this study is to explain the influence of the different social media types on consumers and especially on their purchasing decision-making process. In this context, the main problematic of the study is to reveal the role of brand trust and effect of brand trust on the relationship of consumer behavior intention and digital media as a moderator.

\subsection{Sample and Data Collection}

The population of the research includes all of the consumers who use brands in Turkey. The constraints of time and budget restricted data collection, we used a non-probability sample for the purpose of the research. We administrated the survey to my own network of contacts through Social Media (on Facebook, LinkedIn and Twitter). 150 questionnaire were appropriated among the consumers. For the data collection, we used google form and we started to collect the data on the 11 of April 2020 and has finished on the $30^{\text {th }}$ of 2020 . The collection has thus lasted 20 days. 


\subsection{Data analysis process}

Once the design requirements of research and data collection have been established, in the research strategy is the evaluation of data and the results. In current study, the confirmatory factor analysis and the structural equation model technique was used to examine the information.

\section{Results}

\subsection{Demographic variables}

The demographic profiles of the respondents are detailed below. Table 4.1 presents the demographic respondents. The table show the most of the participants are female $(58 \%)$, the ones between the ages of $26-35,(34.7 \%)$, university master $(52.7 \%)$.

Table 4.1: Demographic Variables

\begin{tabular}{|l|l|l|l|}
\hline \multicolumn{2}{|l|}{ Demographic Variables } & Frequency & Percentage \\
\hline Gender & Male & 63 & $42 \%$ \\
& Female & 87 & $58 \%$ \\
\hline Age & $18-25$ & 25 & $16.7 \%$ \\
& $26-35$ & 52 & $34.7 \%$ \\
& $36-45$ & 27 & $18 \%$ \\
& $46-55$ & 46 & $30.7 \%$ \\
\hline Education & Graduate & 3 & $2 \%$ \\
level & Master & 79 & $52.7 \%$ \\
& M.phil. & 53 & $35.3 \%$ \\
& PhD & 15 & $10 \%$ \\
\hline & Total & 150 & $100 \%$ \\
\hline
\end{tabular}

\subsection{Familiarity of Consumer on Daily Internet Usage}

The Internet familiarity of the respondents is introduced in Table 4.2 . The table highlights that $28.7 \%$ of the respondents had been familiar with the Internet for 4-6 year; while the familiarity of $27.3 \%$ of the respondents is up to one hour. The table also demonstrates that the familiarity of $23.3 \%$ of the respondents is between 1-3 hours; while only $20.7 \%$ of the respondents were familiar with the Internet for more than 5 hours. The frequencies reveal that majority of the respondents had been familiar with the Internet for over four hours.

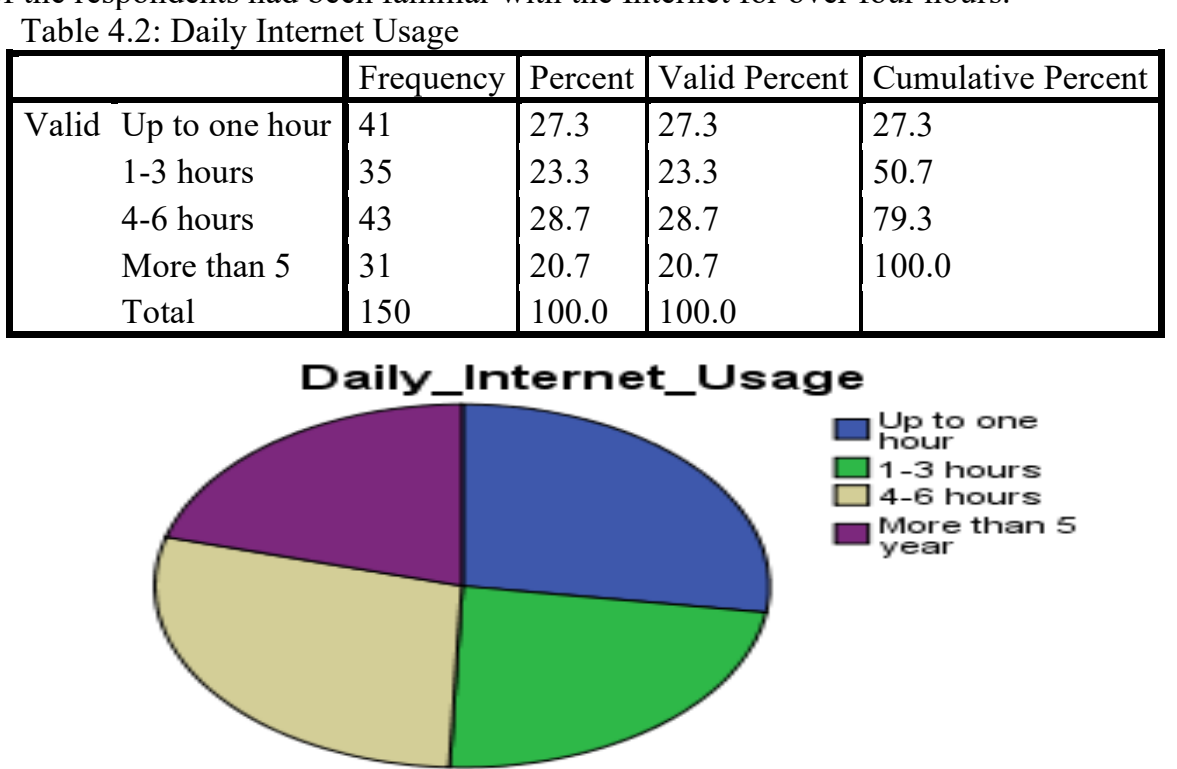

Figure 4.2: Daily Internet Usage

\subsection{Buying behavior of Consumer on digital channel}

The below table 4.3 shows the respondents buying behavior on digital channel. The majority of the respondents who buy products once a week are $39.3 \%$ followed by everyday with $26 \%$ and several times a week with $22.7 \%$. In other words, several times a month and once a month are $8.7 \%$ and $3.3 \%$ respectively. The below frequency table and pie chart shows frequency distribution of buying product on digital channel of respondents. 
Table 4.3: Buying products on digital Channel

\begin{tabular}{|l|l|l|l|l|}
\hline & Frequency & Percent & Valid Percent & Cumulative Percent \\
\hline Valid Everyday & 39 & 26.0 & 26.0 & 26.0 \\
Several times a week & 34 & 22.7 & 22.7 & 48.7 \\
Once a week & 59 & 39.3 & 39.3 & 88.0 \\
Several times a month & 13 & 8.7 & 8.7 & 96.7 \\
Once a month & 5 & 3.3 & 3.3 & 100.0 \\
Total & 150 & 100.0 & 100.0 & \\
\hline
\end{tabular}

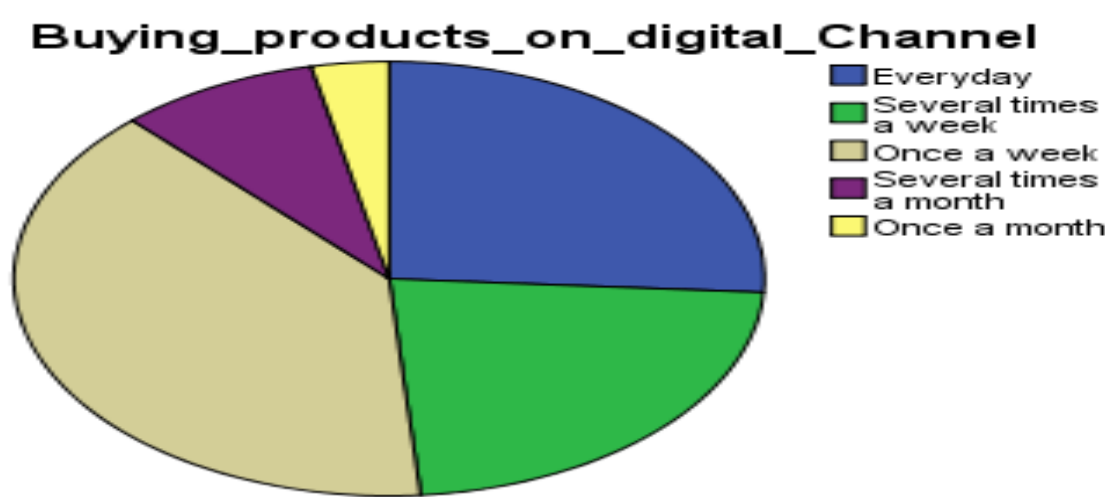

Figure 4.3: Buying products on digital Channel

\subsection{Validity and Reliability Analysis}

Before applying to structural equation modeling, measurement model has been tested with Anderson \& Gerbing's (1988) two-stage approach. The latent variables in the measurement model are respectively digital media marketing, brand trust and consumer behavior. The measurement model has provided the acceptable fit statistics $\left(\chi^{2} / \mathrm{df}=4.2 ; \mathrm{GFI}=.92 ; \mathrm{AGFI}=.87 ; \mathrm{TLI}=.94 ; \mathrm{CFI}=.95 ; \mathrm{RMSEA}=.08\right)$. Validity and reliability analysis related with the measurement model are demonstrated in Table 4.3.

Table 4.4: Validity and Reliability analysis

\begin{tabular}{|c|c|c|c|c|c|}
\hline Variable Name & Items & $(\mathrm{CR})$ & Loadings & (AVE) & Cronback Alpha \\
\hline \multirow[t]{7}{*}{ Digital Media Marketing } & DMM-1 & \multirow[t]{7}{*}{0.928} & 0.649 & \multirow[t]{7}{*}{0.563} & \multirow[t]{7}{*}{0.89} \\
\hline & DMM-2 & & 0.654 & & \\
\hline & DMM-3 & & 0.705 & & \\
\hline & DMM-4 & & 0.850 & & \\
\hline & DMM-5 & & 0.755 & & \\
\hline & DMM-6 & & 0.876 & & \\
\hline & DMM-7 & & 0.786 & & \\
\hline \multirow[t]{5}{*}{ Brand Trust } & BT_1 & \multirow[t]{5}{*}{0.924} & 0.826 & \multirow[t]{5}{*}{0.765} & \multirow[t]{5}{*}{.088} \\
\hline & BT 2 & & 0.835 & & \\
\hline & BT 3 & & 0.856 & & \\
\hline & BT_ 4 & & 0.903 & & \\
\hline & BT 5 & & 0.913 & & \\
\hline \multirow[t]{6}{*}{ Consumer behavior } & CBI-1 & \multirow[t]{6}{*}{0.863} & 0.768 & \multirow[t]{6}{*}{0.678} & \multirow[t]{6}{*}{0.87} \\
\hline & CBI-2 & & 0.834 & & \\
\hline & CBI-3 & & 0.765 & & \\
\hline & CBI-4 & & 0.856 & & \\
\hline & CBI-5 & & 0.786 & & \\
\hline & CBI-6 & & 0.859 & & \\
\hline
\end{tabular}

Confirmatory factor analysis loads of the digital media marketing variable have ranged from 0.64 to 0.87 . Composite reliability (CR) value related with the factor is 0.928 ; and average variance extracted (AVE) is 0.563 . Confirmatory factor analysis loads related with brand trust variable have ranged from 0.82 to 0.91 . CR value related with the factor is 0.924 and AVE value is 0.765 . Confirmatory factor analysis loads related with the consumer behavior variable have ranged from 0.76 and 0.85 . CR value related with the factor is 0.863 and AVE value is 0.678 .

As both the fit indices and item loads of each factor are high in acceptable levels (>.69); it can be said that convergent validity is ensured for the dimensions used in the measurement model. Discriminant validity has been 
calculated using the AVE results that are between 0.56 and 0.76 . AVE values exceeded the square of phi estimates for the constructs, providing discriminant validity. Thus, all factors in the model are in different structure from each other and discriminant validity was ensured (Anderson \& Gerbing, 1988; Fornell \& Larcker, 1981). Thus; it is possible to say that the measurement model is valid and reliable.

\subsection{Correlation Statistics}

Correlations among the constructs in research model is shown in Table 4.5. According to the Table 4.5 correlation values between the structures in the model have ranged from .715 and .977 .

Table 4.5: Correlations

\begin{tabular}{|ll|l|l|l|}
\hline & & Digital media advertising & Brand Trust & Consumer behavior \\
\hline Digital media advertising & Pearson Correlation & 1 & $.728^{* *}$ & $.977^{* *}$ \\
& Sig. (2-tailed) & & .000 & .000 \\
& $\mathrm{~N}$ & 150 & 150 & 150 \\
\hline Brand Trust & Pearson Correlation & $.728^{* *}$ & 1 & $.715^{* *}$ \\
& Sig. (2-tailed) & .000 & & .000 \\
& $\mathrm{~N}$ & 150 & 150 & 150 \\
\hline Consumer buyer & Pearson Correlation & $.977^{* *}$ & $.715^{* *}$ & 1 \\
Intention & Sig. (2-tailed) & .000 & .000 & \\
& $\mathrm{~N}$ & 150 & 150 & 150 \\
\hline
\end{tabular}

**. Correlation is significant at the 0.01 level (2-tailed).

\subsection{Structural Model and Hypotheses Test}

In order to test the hypotheses of the research; structural equation modeling has been used. Structural model is shown in below table.

Table 4.6: Results of the hypotheses in the research model

\begin{tabular}{|l|l|l|l|l|l|l|}
\hline $\begin{array}{l}\text { Hypothes } \\
\text { is }\end{array}$ & Path Coefficient & $\begin{array}{l}\text { Coefficie } \\
\text { nt }\end{array}$ & $\begin{array}{l}\text { Stand. } \\
\text { Dev }\end{array}$ & $\begin{array}{l}\text { T- } \\
\text { value }\end{array}$ & $\begin{array}{l}\text { P- } \\
\text { values }\end{array}$ & $\begin{array}{l}\text { Decisio } \\
\text { n }\end{array}$ \\
\hline $\mathrm{H}_{1}$ & $\begin{array}{l}\text { Digital media marketing-> consumer } \\
\text { behavior }\end{array}$ & 0.70 & 0.127 & 13.368 & 0.005 & Agree \\
\hline $\mathrm{H} 2$ & Digital media marketing-> Brand trust & 0.18 & 0.070 & 2.589 & 0.000 & Agree \\
\hline
\end{tabular}

Table 4.6 indicates that $\mathrm{H} 1$ hypothesis, which suggests that digital media marketing has a positive effect on consumer behavior, is accepted $(\beta=.70 ; t=13.368 ; p<.001)$ as the results of (Pjero \& Kërcini, 2015). H2 hypothesis, which suggests that digital media marketing has a positive effect on brand trust, is also accepted $(\beta=.18$; $\mathrm{t}=2.589 ; \mathrm{p}<.05)$ (Tümer, Aghaei, Öney, \& Eddine, 2019).

\subsection{Testing the moderator hypothesis and results}

In the section above, the direct relationship between the digital media marketing, brand trust and consumer behavior was discussed. In this section, the moderating role of the brand trust between the digital media marketing and the consumer behavior was discussed. The moderation effect of the moderating variable on the interaction between the independent and dependent variables, should be measured (Holmbeck, 1997), therefore, to test the moderation hypothesis, a separate model was developed, in which the moderating variable was used between the independent and dependent variables to test the impact of the standardized moderating score. In this study, Smart PLS 3.0 was used to test the moderation hypotheses, and throughout this process, the consumer behavior was expressed in the digital media marketing, the brand trust served as the moderating variable. Moreover, the interaction term multiplied the scores that were obtained from the digital media marketing and brand trust. The standardized values of these constructs were used as suggested by Aiken, West, \& Reno, (1991) to avoid the problem of Multicollinearity. By doing this process, the significant correlation between the constructs and the interaction term did not make any kind of problem in testing the moderating variable (Ozdogan \& Altintas, 2010).

\subsection{Brand Trust: as a moderator}

In this study, the moderating influence of brand trust was tested considering the relationship between the digital media marketing and the consumer behavior. Table 4.7 elaborates the findings of the brand trust effects on the relationship between the digital media marketing and the consumer behavior. 
Table 4.7: Testing the moderator hypothesis and results

\begin{tabular}{|l|l|l|l|l|l|l|}
\hline $\begin{array}{l}\text { Hypothesi } \\
\text { s }\end{array}$ & Path Coefficient & $\begin{array}{l}\text { Coeff } \\
\text { - }\end{array}$ & $\begin{array}{l}\text { Stand. } \\
\text { Dev }\end{array}$ & $\begin{array}{l}\text { T- } \\
\text { value }\end{array}$ & $\begin{array}{l}\text { P- } \\
\text { value }\end{array}$ & $\begin{array}{l}\text { Decisio } \\
\text { n }\end{array}$ \\
\hline & $\begin{array}{l}\text { Digital media marketing ->Consumer } \\
\text { behavior }\end{array}$ & 0.70 & 0.127 & 13.368 & 0.005 & Agree \\
\hline H3 & BT*DMM -> CBI & 0.220 & 0.144 & 2.447 & 0.035 & Agree \\
\hline
\end{tabular}

\section{Conclusion}

In this investigation, the relations between digital media marketing, brand trust and consumer behavior have been examined. As a matter of first importance, the validity and reliability investigation of the estimation model has been applied in the examination. When the validity and reliability of the estimation model has been affirmed, the relations between the inactive factors in the model have been tried with auxiliary condition model. Breaking down the connection between digital media marketing and consumer behavior, it has been reasoned that digital media marketing has a very significant effect on consumer behavior. It is likewise observed that this outcome underpins the discoveries in the important writing (Bilal, Shafiq, Ahmad, \& Khan, 2014; Dehghani \& Tumer, 2015). Concerning the connection between brand trust and digital media marketing, digital media marketing is decidedly related on brand trust. It is seen that digital media marketing increments as brand trust increments and this outcome additionally bolsters the writing (Akhtar, Ahmed, et al., 2016; Akhtar, Tahir, \& Asghar, 2016; Mckinney \& Benson, 2013; Schivinski \& Dabrowski, 2016).

\subsection{Limitations and Future Studies}

This examination has been closed inside the system of three restrictions. The main confinement of the examination is that the exploration is likewise led on brands consumers. In addition, aftereffects of the examination have been acquired by an online survey technique. Like the other online survey, the example in this investigation incorporates just the ones who are eager to respond to the inquiries in the study and this causes the subsequent restriction. Additionally, as the mental states and the states of the members are not known, the unwavering quality of the appropriate responses can likewise be faulty. The last constraint of the examination is the inclination of accommodation testing strategy. Because of the trouble to arrive at all the populace subject to the exploration, convenience sampling method has been picked. In any case, it isn't workable for the example to represent to all populace. Thus, generalization may not be made.

Upon this investigation; there might be a few proposals for additional examinations. The extent of this exploration is consumers who use brands in Turkey. Thinking about this reality; for the future examinations, items from various classifications and consumers from various nations might be picked and near investigations may be done. What's more, there might be considers which incorporate both the product and service. Moderator impacts of the factors, for example, age, sexual orientation, salary level on the relationship of digital media marketing and consumer behavior can likewise be the subject of future investigations.

\section{References}

Ahmed, M. A., \& Zahid, Z. (2014). Role of social media marketing to enhance CRM and brand equity in terms of purchase intention. Asian Journal of Management Research, 4(3), 533-549.

Aiken, L. S., West, S. G., \& Reno, R. R. (1991). Multiple regression: Testing and interpreting interactions. Sage.

Akhtar, N., Ahmed, I., Jafar, H. Y., Rizwan, A., \& Nawaz, J. M. (2016). The Impact of Packaging, Price and Brand Awareness on Brand Loyalty: A Reseller Perspective in Mobile Sector of Pakistan. International Review of Management and Business Research, 5(3), 790-807.

Akhtar, N., Tahir, M., \& Asghar, Z. (2016). Impact of Social Media Marketing on Consumer Purchase Intention. International Review of Social Sciences, 4, 385-394.

Al-Dhuhli, I., \& Ismael, S. (2013). The Impact of social media on consumer buying behaviour. Unpublished Master's Project, Sultan Qaboos University.

Anderson, J. C., \& Gerbing, D. W. (1988). Structural equation modeling in practice: A review and recommended two-step approach. Psychological Bulletin, 103(3), 411.

Arnott, D. C., Wilson, D., Mukherjee, A., \& Nath, P. (2007). Role of electronic trust in online retailing. European Journal of Marketing.

Atulkar, S. (2020). Brand trust and brand loyalty in mall shoppers. Marketing Intelligence \& Planning.

Baird, C. H., \& Parasnis, G. (2011). From social media to social customer relationship management. Strategy \& Leadership.

Bhandari, M., \& Rodgers, S. (2018). What does the brand say? Effects of brand feedback to negative eWOM on brand trust and purchase intentions. International Journal of Advertising, 37(1), 125-141.

Bilal, M., Shafiq, M., Ahmad, I., \& Khan, I. (2014). First principle studies of structural, elastic, electronic and optical properties of $\mathrm{Zn}$-chalcogenides under pressure. Journal of Semiconductors, 35(7), 72001. 
Boateng, S. L., \& Narteh, B. (2016). Online relationship marketing and affective customer commitment-The mediating role of trust. Journal of Financial Services Marketing, 21(2), 127-140.

Chang, H. H., \& Wu, L. H. (2014). An examination of negative e-WOM adoption: Brand commitment as a moderator. Decision Support Systems, 59, 206-218.

Chinomona, R. (2016). Brand communication, brand image and brand trust as antecedents of brand loyalty in Gauteng Province of South Africa. African Journal of Economic and Management Studies.

Coon, M. (2010). Social media marketing: successful case studies of businesses using facebook and youtube with an in-depth look into the business use of twitter. Unpublished Term Project, Stanford University, -2010.

Dahnil, M. I., Marzuki, K. M., Langgat, J., \& Fabeil, N. F. (2014). Factors influencing SMEs adoption of social media marketing. Procedia-Social and Behavioral Sciences, 148, 119-126.

Dastan, I., \& Geçti, F. (2014). Relationships among utilitarian and hedonic values, brand affect and brand trust in the smartphone industry. Journal of Management Research, 6(2), 124.

De Vries, L., Gensler, S., \& Leeflang, P. S. H. (2012). Popularity of brand posts on brand fan pages: An investigation of the effects of social media marketing. Journal of Interactive Marketing, 26(2), 83-91.

Dehghani, M., \& Tumer, M. (2015). A research on effectiveness of Facebook advertising on enhancing purchase intention of consumers. Computers in Human Behavior, 49, 597-600.

Dutton, K., Coady, A., Pisoni, D., \& Woody, W. E. (2010, December 30). Location-based promotion for a mobile communication network. Google Patents.

Fornell, C., \& Larcker, D. F. (1981). Structural Equation Models with Unobservable Variables and Measurement Error: Algebra and Statistics. Journal of Marketing Research, 18(3), 382-388. https://doi.org/10.2307/3150980

Groß, M. (2015). Mobile shopping: a classification framework and literature review. International Journal of Retail \& Distribution Management.

Habibi, M. R., Laroche, M., \& Richard, M.-O. (2014). The roles of brand community and community engagement in building brand trust on social media. Computers in Human Behavior, 37, 152-161.

Holmbeck, G. N. (1997). Toward terminological, conceptual, and statistical clarity in the study of mediators and moderators: Examples from the child-clinical and pediatric psychology literatures. Journal of Consulting and Clinical Psychology, 65(4), 599.

Hwang, K., \& Zhang, Q. (2018). Influence of parasocial relationship between digital celebrities and their followers on followers' purchase and electronic word-of-mouth intentions, and persuasion knowledge. Computers in Human Behavior, 87, 155-173.

Kim, E., Sung, Y., \& Kang, H. (2014). Brand followers' retweeting behavior on Twitter: How brand relationships influence brand electronic word-of-mouth. Computers in Human Behavior, 37, 18-25.

Krbová, P., \& Pavelek, T. (2015). Generation Y: Online shopping behaviour of the secondary school and university students. Acta Universitatis Agriculturae et Silviculturae Mendelianae Brunensis, 63(2), 567-575.

Kumar, S. S., \& Rajaram, Y. (n.d.). Old Communication, New Fashioned Way: Branding Life Style products to Target Market through Social Networking Sites.

Lu, H., \& Hsiao, K. (2009). Gender differences in reasons for frequent blog posting. Online Information Review.

Mckinney, M., \& Benson, A. (2013). The value of brand trust. Journal of Brand Strategy, 2(1), 76-86.

Ngo, H. M., Liu, R., Moritaka, M., \& Fukuda, S. (2020). Urban consumer trust in safe vegetables in Vietnam: The role of brand trust and the impact of consumer worry about vegetable safety. Food Control, 108, 106856.

Ozdogan, F. B., \& Altintas, M. H. (2010). Parent-adolescent interaction and the family's effect on adolescent TV skepticism: an empirical analysis with Turkish consumers. Young Consumers.

Phua, J., Jin, S. V., \& Kim, J. J. (2017). Gratifications of using Facebook, Twitter, Instagram, or Snapchat to follow brands: The moderating effect of social comparison, trust, tie strength, and network homophily on brand identification, brand engagement, brand commitment, and membership intention. Telematics and Informatics, 34(1), 412-424.

Pintado, T., Sanchez, J., Carcelén, S., \& Alameda, D. (2017). The effects of digital media advertising content on message acceptance or rejection: brand trust as a moderating factor. Journal of Internet Commerce, 16(4), 364-384.

Pjero, E., \& Kërcini, D. (2015). Social media and consumer behavior-How does it works in albania reality? Academic Journal of Interdisciplinary Studies, 4(3 S1), 141.

San, L. I. M. Y. (2016). The Influence of Brand Trust, Brand Association, Brand Loyalty and Brand Equity in Cyberspace: Moderating Effect of Online Purchase Frequency.

Sawaftah, D., Calıcioglu, C., \& Awadallah, R. (2020). The relationship between viral marketing and consumer purchase intention, the moderator role of brand image and age: Evidence from smartphone users in North Cyprus. Management Science Letters, 10(6), 1307-1320.

Schivinski, B., \& Dabrowski, D. (2016). The effect of social media communication on consumer perceptions of brands. Journal of Marketing Communications, 22(2), 189-214. 
Sung, Y., \& Kim, J. (2010). Effects of brand personality on brand trust and brand affect. Psychology \& Marketing, 27(7), 639-661.

Swift, P. E., \& Hwang, A. (2013). The impact of affective and cognitive trust on knowledge sharing and organizational learning. The Learning Organization.

Tatar, Ş. B., \& Eren-Erdoğmuş, İ. (2016). The effect of social media marketing on brand trust and brand loyalty for hotels. Information Technology \& Tourism, 16(3), 249-263.

Tedeschi, M., Galli, G., \& Martini, M. C. (2017). On and Off-line Purchase Intention: the Role of Brand Trust as Moderator of Risk Perception. Journal of Emerging Trends in Marketing and Management, 1(1), $194-203$.

Tümer, M., Aghaei, I., Öney, E., \& Eddine, Y. N. (2019). The impact of traditional and social media marketing on customers' brand trust and purchase intentions in the Turkish airline market. Journal of Research in Emerging Markets, 1(4), 55-68.

Vafaei, S. A., \& Fekete-Farkas, M. (2017). The effect of social media on customer behaviour and firms' activities.

Vij, S., \& Sharma, J. (2013). An empirical study on social media behaviour of consumers and social media marketing practices of marketers. In 5th IIMA Conference on Marketing in Emerging Economies.

Wang, Z., \& Kim, H. G. (2017). Can social media marketing improve customer relationship capabilities and firm performance? Dynamic capability perspective. Journal of Interactive Marketing, 39, 15-26.

Yadav, M., \& Rahman, Z. (2017). Social media marketing: literature review and future research directions. International Journal of Business Information Systems, 25(2), 213-240.

Yang, M.-H., \& Chiang, C.-T. (2017). Customer Relationship And Trust: Customer Role As A Moderator. In 4thAcademic International Conference on Business, Marketing and Management (p. 16).

Ziyadin, S., Doszhan, R., Borodin, A., Omarova, A., \& Ilyas, A. (2019). The role of social media marketing in consumer behaviour. In E3S Web of Conferences (Vol. 135, p. 4022). EDP Sciences. 